\title{
A Geographic Magazine as a Class Project
}

\section{Elizabeth Wolff}

To cite this article: Elizabeth Wolff (1921) A Geographic Magazine as a Class Project, Journal of Geography, 20:5, 191-192, DOI: 10.1080/00221342108984503

To link to this article: http://dx.doi.org/10.1080/00221342108984503

\section{曲 Published online: 14 Feb 2008.}

$\sqrt{6}$ Submit your article to this journal $\llbracket$

Џ Article views: 2

Q View related articles $\sqsubset$ 


\title{
A GEOGRAPHIC MAGAZINE AS A CLASS PROJECT
}

\author{
ELIZABETH WOLFF \\ Alger School, Detroit, Michigan
}

This project was worked out by the $6 \mathrm{~A}$ class of the Alger School, Detroit, Michigan, with the assistance of the other geography classes.

Arm

To correlate the work of the various geography classes by having each class contribute something toward the enjoyment of all and at the same time profit by their work and give useful and interesting information to others.

\section{Situation}

The $6 \mathrm{~A}$ class had been studying the new countries of Europe for several weeks and with the aid of magazines, newspapers, maps, etc., had prepared some very fine recitations. One day in class someone mentioned the fact that it would be nice if the information which the various members of the committees had secured with such difficulty might be passed on to the other classes. A number of suggestions were made. One of the girls suggested that other classes often had recitations that were just as interesting as those given in the $6 \mathrm{~A}$ class, and proposed that a magazine or paper be published with the cooperation of all these classes. She was told that there were no objections and that it was a very fine idea if it could be carried out. The class was sure that it could be and wanted to organize at once. However it was dec:ded that they wait until the next day and consult a number of the magazines and newspapers before doing anything definite.

\section{Organization and Planning}

The next day a chairman was chosen to take charge of the organization work. The name of the magazine was the question of first importance. A long list was suggested but the title, "The Alger Geographic," received a majority of votes. Then the officers and departments necessary for carrying out their plans were taken up. The following were decided upon after a great deal of discussion:

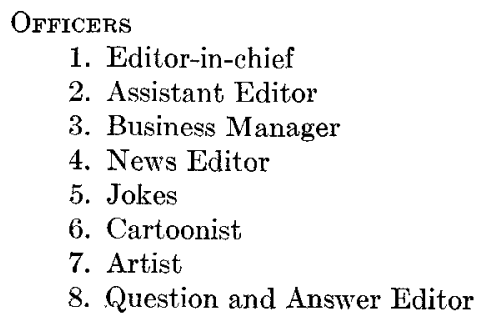




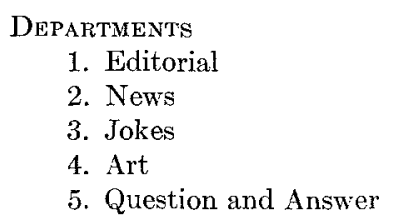

There were to be two reporters from each class who were to hand in the class news, jokes and other contributions from their respective classes, to the head of each department. Each officer had the privilege of selecting two assistants, thus forming a committee of three to arrange and pass judgment on the papers handed in. A continued story plan was adopted and given the title of "Around the World." It was to follow the travels of a little girl in different parts of the world.

The magazine was to be published in typewritten form every two weeks at first, but it proved to be more of a task than was expected, so it is now published only once a month. A regular meeting of all the officers and reporters is held at the beginning of each month and once just before it is published to correct errors, etc.

\section{Results}

The magazine has been a source of great interest to everyone. The classes can hardly wait for their turn to come when a number is published. Each room is allowed to have it three days and a part is read each day during the study period. Quite often the request to take it home is made but has to be refused.

The children seem as anxious and pleased at having their work shown in this form as if they were really having it printed. But do not think for a moment that they are always satisfied. They are not. Very often this comment is heard, especially from the boys: "Oh, that's all right, but I think he (or she) could have done better if they had done so-and-so." These criticisms are not passed by but are taken up at the regular meetings and carefully considered. So far they have in most cases proven very helpful.

\section{Conclusions}

The work on this project has not only been intensely interesting but has shown very clearly what children expect and enjoy. It has been carried out much more efficiently than was expected and is being improved so rapidly that there is no doubt about the fact that it is thoroly worth while. It offers many opportunities for correlation especially with the art and literature departments in the school. Originality receives great encouragement and thus gives the individual child a chance to show powers no one dreamed he possessed. 